\title{
Application of Information Technology in Preschool Aesthetic Teaching from the Perspective of Sustainable Management
}

\author{
Ruei-Jen Diana Fan ${ }^{1}\left(\mathbb{D}\right.$ and Paul Juinn Bing Tan ${ }^{2, *}$ \\ 1 Department of Early Childhood and Family Education, National Taipei University of Education, 134 sec.,2, \\ Ho-ping E. Rd., Taipei 106, Taiwan; dianafan7@gmail.com \\ 2 Department of Applied Foreign Languages, National Penghu University of Science and Technology, \\ Magong 880, Taiwan \\ * Correspondence: pashatan@yahoo.com
}

Received: 2 February 2019; Accepted: 20 March 2019; Published: 11 April 2019

check for updates

\begin{abstract}
The present study investigates the current status of aesthetic education as implemented in information technology by preschool teachers in New Taipei City. To that end, stratified random sampling of preschool teachers in New Taipei City was conducted, and the selected teachers, 235 in total, then answered a questionnaire developed specifically for the study. The survey results indicated that "teacher" was the job title/position of most of the respondents, the largest percentage of whom were more than 41 years of age and had an education level consisting of a qualification received from a teacher's college or university of education. Moreover, the results indicated that the teaching models employed by the majority of respondents focused on "thematic teaching." In regards to their integration of information technology in their teaching of aesthetic education, the survey results indicated that the teachers obtained the highest average score for the "knowledge of information technology" dimension. Meanwhile, the dimension for which the respondents obtained the highest average score in terms of aesthetic teaching itself was the dimension pertaining to aesthetic cognition. Generally speaking, survey respondents from different backgrounds did not differ significantly in terms of their overall intentions regarding the use of aesthetic teaching, but there was a significant and positive relationship between those overall intentions and the current status of information technology integration into aesthetic education.
\end{abstract}

Keywords: aesthetics; aesthetic education; technology information; preschool education; teaching model; preschool school

\section{Introduction}

At the Sustainable Development Summit in 2002, the former Secretary-General of the United Nations, Kofi Annan, argued that "Education is the key to achieving sustainable development" [1].

In Taiwan, a formal education system is responsible for educating citizens. Relatedly, it has been argued that education for sustainable development is primarily a matter of investment and that a country that seeks to ensure its future development must likewise ensure that its educational efforts have sufficient resources, both financial and otherwise. Along the same lines, the European Economic Commission of the United Nations expressed the view that, in addition to being a human right, education is an absolute requirement for sustainable development and good management [2]. Accordingly, interested parties should promote the view that education is absolutely necessary for sustainable development.

Ultimately, perseverance is required to ensure that education for sustainable development is achieved, and the goal of such educational efforts can be summarized as ensuring that everyone, 
everywhere has the chance to receive an education. At the same time, the crucial role that individual lifestyles and behaviors play in ensuring stability and positive societal change must be acknowledged [3].

In short, the implementation of education for sustainable development in formal educational systems is imperative, as education is the most powerful and critical tool for achieving positive societal change, with aesthetic education being the most important aspect of education in general. In general terms, aesthetic education can be defined as an atmosphere of literacy that leads to societal progress and the betterment of individual human hearts. Relatedly, John Dewey [4] has advocated for the centrality of "life and education, education and life" because education is critical to ensuring lives of truth, goodness, and beauty. In this view, art is embodied by the earth, the window to beauty is the soul, and beauty itself springs forth through our experiences of kindness and truth, with schools being a primary location for the experience of said kindness, truth, and, therefore, beauty. As such, teachers can be viewed as navigators who guide students in the art of life, with education being the process by which a person is made. The adage "it takes a hundred years to nurture a generation of good men" reveals that education is fundamental to sustainable development, with the soul of education being aesthetics. Relatedly, the environment in which such personal development occurs is of critical importance, while aesthetic planning and education can be used to ensure that the environments in which we live are harmonious and peaceful [1]. In other words, aesthetics are a means by which we can shape our educational systems, which again, are themselves critical to sustainable development. A sense of beauty and the capacity to complement one another are, in this sense, a necessity, as well as a means by which the soul can exhibit both vitality and flexibility.

In order to achieve the goals of education, it is important to answer these questions posed by Henno Theisens [5] in 2008: (1) "How can education help individuals achieve their fullest potential?" and (2) "How can today's schools be transformed into the type of teaching and learning environments that make individuals lifelong learners and prepare them for the 21st century?"

In Taiwan, each student spends about 6-8 h per day in school from primary school through junior high school, for a total of approximately $1200-1600 \mathrm{~h}$ per year. As such, it is clear that "school" is among the most important environments in which the youth of the country experience life. Its importance is even greater insofar as it is at these ages that an individual's personality is shaped, both in terms of cognitive and emotional development, as well as socialization [6]. In short, the formal education a child receives in school covers a substantial amount of time during a critical period of his or her personal development. Accordingly, policy makers could give less attention to aesthetic education and planning if they would endeavor to ensure that schools as physical spaces are appropriately combined with e-learning curricula.

\section{Literature}

Preschool education is the first step in education, and aesthetic education should begin at this stage. Through the implementation of a teaching design that promotes aesthetic experiences in preschool learning and enables subtle daily learning to occur, a natural sense of aesthetic awareness can be cultivated, such that aesthetic education can continue in a sustainable manner. The teaching models used in preschools in Taiwan can be described as follows:

\subsection{Taiwan's Preschool Teaching Models}

- Unit Teaching

A unit is a complete learning activity that revolves around an important issue of daily life. It utilizes psychological organization to integrate the life and educational activities of young children, and provides clear objectives, contents, methods, and assessments; flexible adjustments can also be made during unit activities to suit the interests of a young child. During unit teaching, a systematic and planned unit teaching design is utilized, and the age, ability, needs, and learning interests of a young child are also considered, so as to establish an integrative link between life and education and 
enable a young child to learn problem solving methods. When aesthetic teaching-related activities are being carried out, aesthetic activities can be treated as a major or minor unit, and during the teaching process, a teacher has to constantly observe the learning performance of a young child based on his or her interests and ability and correct the teaching approach accordingly.

- Learning Zone Teaching

For the past decade or so, spatial planning and meaning interpretation have led to various interpretations, as well as the evolution of the name and form of the term "learning zone" (e.g., "learning corner," "corner teaching," "big learning zone"). A teacher takes on the role of the receiver, observer, listener, and guide, and, more importantly, respects the choices made by the young child during independent exploration, as well as his or her personal interests, and allows him or her to learn freely at his or her own pace within the learning zone.

- Thematic Teaching

Thematic teaching is the mainstream curriculum model that many preschools in Taiwan are currently using. Thematic teaching is a form of emergent curriculum in which lessons develop and emerge gradually. Next, the teacher will utilize prepared learning scenarios and available learning materials to jointly develop activity contents and paths with the young child and determine the next set of learning content. Each branch of a thematic network can be extended and broadened to accommodate a young child's learning experience and interests; this also helps a teacher to consider and organize the activities and contents that could be integrated into the thematic activities. It should be noted that a young child builds his or her knowledge through his or her interactions with the people, events, and things within an environment.

\section{- Project Teaching}

The project is usually executed by the entire class, class groups, or an individual child, and even when a project is executed by an entire class, each young child can still explore specific theme-related topics individually or in groups. Therefore, the "hands-on" element is the most important when project teaching is being used to execute aesthetic teaching activities and exploration, and a young child can better understand, experience, create, and appreciate beauty through a hands-on experience.

The four teaching methods discussed above are the most common methods used in preschools. Generally speaking, aesthetic teaching activities utilize just a couple of common teaching principles. As such, the primary components of aesthetic education for children consist of the following:

- Experiences: A young child should be provided with experiences that are real and specific and provide opportunities for him or her to engage in repeated practice, such that old and new experiences can be linked to establish meaningful learning experiences that will enrich his or her aesthetic imagination and creativity.

- Relevance to life: For a young child, life is learning, and learning is life. He or she can only acquire and express an aesthetic sense and attitude in a seamless manner when there is a contextual meaning to learning, and when the content learned can be applied to his or her life, integrated into his or her life experiences, and linked to his or her society and culture.

- Gamification: A young child learns most naturally through games. With the transformation of abstract cognitive concepts into game content, a young child can learn through play and become more interested in and motivated about learning. This approach is an important dimension of affective learning in aesthetic education, as it respects individual differences in artistic expression and accepts the thoughts and feelings that young children convey through their creations.

- Diversity: The diversification of teaching methods to provide a variety of activity formats (such as individual, team-, and group-based activities) can bring out the fullest potential of teaching design and allow for a young child's individualized development to be accommodated. The diversification of teaching resources provides a young child with a rich variety of materials to 
explore during exposure to different sensory learning stimuli; this prevents aesthetic teaching from becoming just another activity in the main curriculum.

It is generally understood that solutions related to aesthetics are multifaceted in nature and address social environments, value systems, personalities, educational levels, and other aspects of the objects of said solutions [7]. With preschool education forming the foundation of education, the proper utilization of information technology, in both tangible and intangible learning environments, will surely help to cultivate a child's values and healthy personality traits.

\subsection{Significance of Integrating Information Technology into Teaching}

According to Papadakis and Kalogiannakis (2017) [8], information technology is spreading and growing rapidly, suggesting that the technological tools of the next generation will be able to provide holistic opportunities for creative use. Meanwhile, parents and educators are also striving to reap the potential educational benefits of such technological tools for their children and/or students. However, the process of selecting technological tools that are suitable for childhood education is often difficult. The infrastructure of communication technology and information in Taiwan is extremely competitive [9].As such, e-learning has become a major model for teaching in Taiwan's schools, even including preschools, in recent years. For instance, teachers are using tablets to help young children develop and enhance their investigative and data searching skills with regard to class content. Using these devices, young children are able to easily review their own actions and answers before working on the next problem, which increases their exploration and helps to unleash their creativity and intellectual potential. Eryilmaz, Adalar, and Icinak (2015) [10] found that the application of teaching methods that integrate digital learning is beneficial, providing more learning opportunities than traditional learning environments; learners can learn whenever and wherever they want to, there is more cooperation and interaction among students, and learners are able to execute their learning plans, select the appropriate resources based on their learning levels, and acquire responsibility and confidence with respect to learning. However, the same study also indicated that the major problems encountered during the learning and teaching process involve the teaching software and teaching strategies pertaining to the application of information technology; instead of separating them from the teaching content, the techniques of technology application should be integrated into the theoretical foundation, and the need to use them in teaching projects should be emphasized. E-learning can essentially be defined as instruction that is computer assisted [9] and can be accessed from any location, with multimedia teaching efforts being exemplified by applications of the Internet, interactive television, audio and videotapes, computers, $\mathrm{CDs}$, and satellite broadcasting.

Using two motivational models (MMs) suited for course learning (for example, aesthetic, language, mathematics), and formal and informal visual environments that were developed by [10-12], Tan's [9] various empirical studies have utilized media psychology to investigate aesthetic-emotion items treated as adjectives.

A significant body of research in psychology has confirmed general motivation theory as an explanation for learning behavior, as shown in Table 1 Tan's [9].

Table 1. Motivation models (MMs).

\begin{tabular}{lll}
\hline Core Constructs & \multicolumn{1}{c}{ Definitions } & Reference \\
\hline $\begin{array}{l}\text { Extrinsic } \\
\text { motivation }\end{array}$ & $\begin{array}{l}\text { Refers to when teachers wish to apply the concept of information } \\
\text { technology in their teaching model to contribute to the } \\
\text { achievement of different value outcomes than those that would } \\
\text { be achieved through the activity itself, such as improvements in } \\
\text { the teaching skills/satisfaction of teachers, having fun, etc. }\end{array}$ & $\begin{array}{l}\text { Davis, Bagozzi and } \\
\text { Warshaw (1992) }\end{array}$ \\
\hline \multirow{2}{*}{ Subjective norms } & $\begin{array}{l}\text { Refers to when teachers want to teach an activity with no } \\
\text { noticeable enhancements-that is, when no outcomes will be } \\
\text { achieved besides the implementation of the activity itself. }\end{array}$ & \\
\hline
\end{tabular}


For example, two studies applied exploratory factor analysis (EFA) to aesthetic-emotion in order to develop a scale that could be used for measurements of learner motivation [13]. Relatedly, any aspect of e-learning can be employed with preschool teaching models to facilitate a child's understanding of aesthetics and their meaning in daily life.

\subsection{Defining the Integration of Information Technology into Teaching}

The integration of information technology into teaching primarily involves the use of information technology as a teaching tool that supports the teaching tasks of teachers and helps students to learn. Over the years, educators have used various types of information technology to provide innovative ideas in early childhood education [14]. Kalogiannakis et al. (2018) [14] used a software/digital program to teach children aged 5-7 about gravity and the planets through hands-on activities. The results of that study were encouraging, proving that the implementation of information technology in educating children on natural science is very effective. However, there is still a lack of research on the application of information technology in early childhood aesthetic education. Based on the definitions provided by past studies, the following common points have been identified:

Many studies have indicated that information technology can be integrated into various stages of teaching, but issues such as a lack of software and hardware, insufficient administrative support, a lack of professionalism among teachers, and a lack of willingness among teachers can hinder this process. It should be noted that the research participants in these studies consisted mostly of junior high teachers.

Wright (2003) [15] also proposed that teachers could conduct activities using a diverse and extensive range of materials, as well as media-oriented approaches. He believed that art can serve as a link between culture and society, and that aesthetic and artistic activities can stimulate the potential, thinking, creativity, and problem-solving skills of a young child at a deeper level. Clearly, the immediacy and convenience of information technology aligns well with the characteristics of visual art, and through the use of information media, a large and diverse range of art media can be located. Thus, the application of information technology in teaching can enhance a young child's visual and imaginative stimulation in many dimensions.

\subsection{Application of Information Technology in Preschool Teaching}

A computer can produce images and sounds that attract a young child's attention. For a young child, the linking of information technology and learning activities involves not only tool-oriented hardware and software operations and activity arrangements for information courses, but also the creation of an intermediary for interesting digital teaching models that can help him or her acquire positive learning experiences that lead to better teaching effectiveness and creativity [16-19].

To the best of our current understanding, E-learning effectively alters the learning process, including how educational goals are defined and perceived. By taking advantage of E-learning technology, schools can make learning more effective [9]. In consideration of preschool teaching styles, this study utilized the dimensions of teaching technology.

- Internet search engines: Means of self-learning that enable a teacher to look up teaching resources and acquire teaching knowledge: e.g., IE and Google.

- Computer software: Use of software suites to prepare items such as teaching materials, preschooler learning records, course files, and class publications: e.g., Word, PowerPoint, Print Magic, and Power Director.

- Information equipment and hardware: Such equipment and hardware is used to present the teaching content that a teacher has prepared, such that a young child is able to appreciate and understand the content and link it to his or her life. In this manner, learning efficiency is enhanced. Examples of such equipment include computers, single tube projectors, tablets, and opaque projectors. 
- Multimedia software: Multimedia software utilizes sound and video to provide a young child with a multi-sensory learning experience.

- Digital information equipment: Technology products that offer convenient data storage and retrieval are used to record a young child's learning history, which can then be promptly reviewed or discussed. Examples of such equipment include digital cameras, video cameras, and mobile phones.

- Social platforms: The convenience and widespread use of social platforms enable them to serve as tools for conducting discussions with others, sharing teaching experiences and resources, and engaging in interactive learning across borders and various fields of learning. Examples of such platforms include Facebook and Pinterest.

Papadakis, Kalogiannakis and Zaranis $(2016,2018)[20,21]$ used an experimental group and a control group to investigate and compare the use of computers and tablets among children. They showed that both tools had a significant influence on the development of mathematical competence in early childhood education. They conducted another study on the influence of computers and tablets in the development of mathematical competence in early childhood education. The results showed that the inclusion of appropriate software in children's daily lives can make substantial contributions to their comprehension of numbers. The implementation of aesthetic education is intended to allow children to learn through their five senses, that is, sight, sound, smell, taste, and touch. Furthermore, the application of information technology is supplementary and complementary. By incorporating the aesthetic elements of our external environment into software applications, it will be possible for children to get hands-on experiences that allow them to develop creative cognition and affection for their diverse surroundings. However, most researchers have thus far applied information technology to topics that are science-oriented rather than humanities-oriented (such as aesthetics, language, history, and culture [22]).

\subsection{The Concept of Aesthetic Education for Young Children}

- Dewey's concept of aesthetic education

A balanced interaction among four elements, specifically, consummation, doing, unity, and undergoing, is required for a complete experience. Dewey's concept of aesthetic education is based on everyday experience, emphasizing that aesthetics is present in our everyday life and fully experienced through the acts of doing and receiving. A so-called complete experience consists of the interaction between doing and receiving. The integration of emotion refers to the full participation of emotion, which allows the continuation and transformation of the entire experience, and results in the self-completion of an activity and formation of a complete experience.

- Steiner's concept of aesthetic education

Rudolf Steiner (1861-1925) was the founder of Waldorf education and anthroposophy. The aim of Steiner's aesthetic education is to nurture rich, poetic, visual, and imaginative perceptions in young children, and to focus on early sensory development and restoration using aesthetic education as a foundation in order to prevent the subsequent loss of such sensations (Lim, 2004) [23]. Waldorf education considers the influence of temperaments on children and calls for classes that emphasize the principles of imitation, regularity, and repetition; it stresses a balance between manual skills and knowledge, and advocates a learning environment filled with natural materials and soft colors. Class content includes free play activities, as well teacher-designed art, stories, and music. The focus here is on games, art, and aesthetics.

The core values of the two concepts revolve around the idea that young children will absorb all of their class experiences; hence, the learning content provided to young children in a class should be specifically designed to include aesthetic content, since this is the only way young children can absorb and learn. Fan (2003) [24] discussed how the act of being "moved" is a foundation of aesthetic 
education; a child who is moved by his or her environment will develop a better attitude and mind for aesthetics, so learning should be conducted with the senses and experiences in mind.

\subsection{Relationship between Aesthetic Education and Aesthetic Teaching}

- Content of curriculum guidelines for preschool activities

Published by the Ministry of Education, the Curriculum Guidelines for Preschool Activities emphasizes holistic development in preschool education, an educational philosophy that focuses on young children, and opportunities for young children to interact with their living environment [25]. The publication of these guidelines has provided preschool teachers with an important reference with respect to content and learning dimensions; the guidelines stress the importance of integrated age- and personality-appropriate learning and creative diversity, as well as experiences that are relevant to the lives of young children.

- Aesthetic teaching for young children

The content of aesthetic education includes not just visual, auditory, and integrated arts, but also other courses, as well as experiences and activities related to aesthetic appreciation, research, production, and presentation. Looking at the three categories mentioned above, aesthetic education should be explained using the third perspective. Aesthetic teaching for young children should begin with their life experiences and emphasize "art in the real world." This allows for artistic activities that can be understood by young children and cater to their actual needs and interests. Through such activities, young children can engage in complete observational experiences and continuous practice.

- Current state of aesthetic teaching for young children

Existing aesthetics-related studies of preschools in Taiwan have indicated that preschool education service staff mostly base the reflective and assessment aspects of their aesthetic teaching on the learning dimensions and learning capabilities covered in new course outlines. However, due to the difference in the research areas covered by these studies, there may be differences between their research results with respect to the interpretation and implementation of the content, the teaching experience of the participants, and the teaching models utilized. Therefore, this study was executed as a questionnaire study with the aim of exploring the abovementioned issues.

\subsection{Relationship between Information Technology and Aesthetic Teaching}

- Empirical research on the integration of information technology into preschool teaching.

All of the past studies from Taiwan recruited teachers as research participants, utilized the questionnaire survey method, and placed a stronger emphasis on aesthetic teaching. Unlike previous studies, this study revolved around teachers and explored the application of information technology in teaching, as well as the usefulness of information technology equipment in preschooler learning.

- Empirical research on the integration of aesthetic teaching into preschool teaching.

Most previous studies were curriculum studies that employed the action research method to examine aesthetic education; there is currently a lack of Taiwan-based studies on aesthetic education in preschools. By properly integrating information technology into aesthetic education, preschool teachers can bring more diversity to the aesthetic experiences of young children.

- Empirical research on the integration of information technology into aesthetic teaching.

Given the convenience that information technology offers in terms of image processing, the development of a teaching environment with highly interactive learning technology should pair well with art teaching that uses visual images as the main subjects for teaching. Wright (2003) [15] also proposed that teachers should provide a diverse and rich range of materials and take advantage of 
media to conduct their activities. Moreover, in the belief that art connects society and culture, he argued that aesthetic and artistic activities can unleash the potential, thinking, creativity, and problem solving ability of young children at a deeper level. Time has shown that the application of information technology has filled the needs of our society; however, there is still a lack of studies on aesthetic education and teaching in preschools, and this empirical gap was the most important motivation behind this study.

Farris and Sengupta (2016) [26] examined computer education and learning, with a focus on aesthetic and artistic experiences. In that study, Dewey's philosophy was applied to convert the aesthetic experience into a basic form of human experience, such that all other forms of experience can be consolidated and the completeness of the learning experience can be emphasized. These studies demonstrate the immediacy and convenience of information technology, which are considerably compatible with the qualities of visual art. Through information media, it is possible to access a large and diverse range of art media, which can applied in teaching by providing young children with visual and imaginative stimulation across different dimensions.

\section{Research Methods}

Research participants: 36 preschools were randomly sampled. These preschools were contacted via e-mail (as shown in Figure 1).

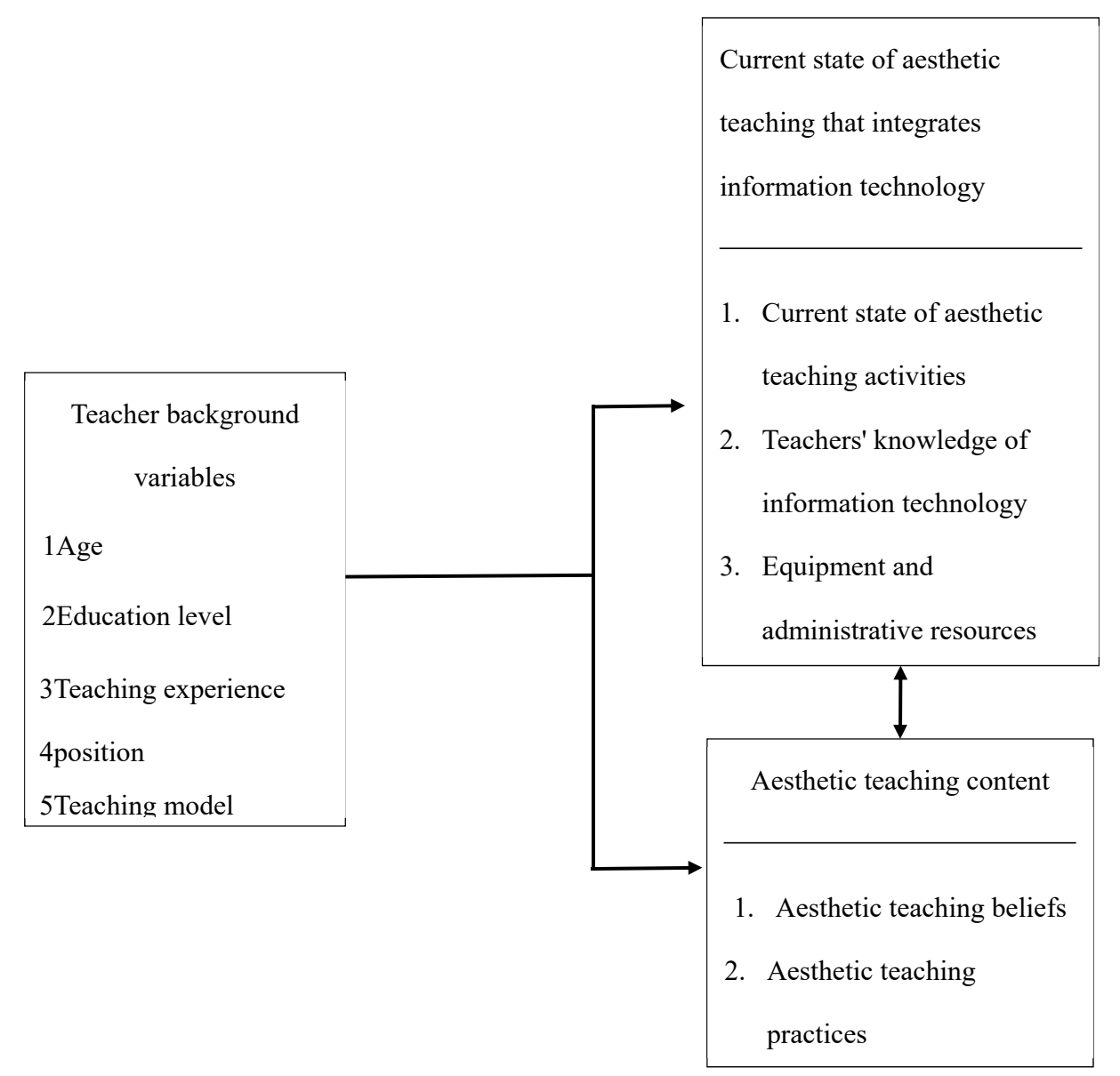

Figure 1. Research framework. 


\section{Research Tools}

\subsection{Preparation of Questionnaire}

- Preliminary draft of the questionnaire: The questionnaire structure was prepared based on the research objectives after reviewing the questions to be answered and the relevant literature. The structure was divided into teacher background variables, the current state of aesthetic teaching that integrates information technology, and aesthetic teaching content, and used to prepare the preliminary draft of the questionnaire.

- Content validity: The relevance of the preliminary questionnaire draft was then ascertained by inviting experts, scholars, and senior teachers from the fields of information technology and preschool education to assist in reviewing the questionnaire's content. The opinions gathered from the expert review served as expert validation for the questionnaire, and, subsequently, the preliminary pre-test questionnaire was prepared.

- Questionnaire pre-test: 60 pre-test questionnaires were administered via random sampling, and 55 valid questionnaires were collected, representing an effective questionnaire recovery rate of 91\%. Based on the pre-test sample's responses to the "Research Questionnaire on the Integration of Information Technology into Aesthetic Teaching by New Taipei City Public Preschool Teachers," a reliability analysis was conducted to test the internal consistency of the questionnaire's overall scale. The questionnaire's total $\alpha$ coefficient was .900, indicating a sufficient level of internal consistency to support the study's results. Likert-type scales with five-level items ("Always" (5 points), "Often" (4 points), "Sometimes" (3 points), "Rarely" ( 2 points), "Never" (1 point)) were utilized to measure two dimensions of aesthetic teaching content, namely, aesthetic teaching beliefs and aesthetic teaching practices.

- Questionnaire administration and collection The questionnaire was administered via e-mail and mail to 36 preschools (sampled from a list of 149 public preschools operated by the Department of Education of the New Taipei City Government) and 272 teachers; 238 were collected, representing a recovery rate of $87.5 \%$, and after excluding three invalid questionnaires that were not completed, a total of 235 questionnaires were made available for analysis, representing a usable rate of $86.3 \%$.

\subsection{Data Processing and Analysis}

- Descriptive statistics

A preliminary descriptive statistical analysis was performed to examine the background variables of the preschool teachers, the state of integration of information technology into aesthetic teaching, and the aesthetic teaching content. This analysis covered the mean, standard deviation, frequency, and percentage values.

- Reliability analysis

For the reliability test, Cronbach's $\alpha$ was used to test and analyze the internal consistency of the questionnaire's dimensions and overall scale.

- One-way analysis of variance

A single factor variance test was carried out to test the differences among the various background variables with regard to their relationship with the state of integration of information technology into aesthetic teaching and aesthetic teaching content. When a statistically significant difference was reached, Scheffe's method was used to perform an a posteriori comparison to understand this difference.

- Pearson product-moment correlation

The Pearson product-moment correlation was used to examine the correlation between the state of the integration of information technology into aesthetic teaching by New Taipei City public preschool teachers and aesthetic teaching content. 


\section{Research Results and Discussion}

\subsection{Background Characteristics of New Taipei City Public Preschool Teachers}

In total 272 questionnaires were administered and 235 were collected, representing a recovery rate of $86.3 \%$. This section aims to analyze the research participants' background variables (age, education level, teaching experience, position, and teaching model) and the corresponding percentage distribution, so that an overall understanding of the research participants' backgrounds can be established (as shown in Table 2).

Table 2. Frequency distribution of teacher background variables.

\begin{tabular}{|c|c|c|c|}
\hline Background Variables & Items & Frequency & $\%$ \\
\hline \multirow{3}{*}{ Age (years) } & $\leq 30$ & 61 & 26 \\
\hline & $31-40$ & 75 & 31.9 \\
\hline & $\geq 41$ years old & 99 & 42.1 \\
\hline \multirow{4}{*}{ Education level } & Master's degree or higher & 82 & 34.9 \\
\hline & $\begin{array}{l}\text { Qualification obtained through a general } \\
\text { university's teacher education program }\end{array}$ & 50 & 21.3 \\
\hline & $\begin{array}{c}\text { Qualification from a teacher's college or } \\
\text { university of education }\end{array}$ & 103 & 43.8 \\
\hline & Others & 0 & 0 \\
\hline \multirow{5}{*}{$\begin{array}{l}\text { Teaching experience } \\
\text { (years) }\end{array}$} & $\leq 5$ & 64 & 27.2 \\
\hline & $6-10$ & 54 & 23 \\
\hline & $11-15$ & 29 & 12.3 \\
\hline & $16-20$ & 34 & 14.5 \\
\hline & $\geq 21$ & 54 & 23 \\
\hline \multirow{4}{*}{ Position } & Substitute teacher & 21 & 8.9 \\
\hline & Teacher & 169 & 71.9 \\
\hline & Teacher with administrative role & 42 & 17.9 \\
\hline & Director & 3 & 1.3 \\
\hline \multirow{5}{*}{ Teaching model } & Unit teaching & 6 & 2.6 \\
\hline & Learning zone teaching & 7 & 3 \\
\hline & Thematic teaching & 175 & 74.5 \\
\hline & Project teaching & 16 & 6.8 \\
\hline & Other & 31 & 12.9 \\
\hline
\end{tabular}

- Age:

61 participants (19.7\%) were aged 30 and below, 75 participants (31.9\%) were aged 31-40, and 99 participants (42.1\%) were aged 41 and above. Age-wise, most of the teachers were 31 years and above. The research results indicated that, despite New Taipei City's annual efforts to recruit new teachers since 2011, the current age distribution of education staff in New Taipei City remains slightly top-heavy.

- Education level:

82 participants (34.9\%) had master's or higher degrees, 50 participants $(21.3 \%)$ had qualifications obtained through a general university's teacher education program, and 103 participants (43.8\%) had qualifications from a teacher's college or university of education. Teachers who graduated from a teacher's college or university of education accounted for the largest percentage of the participants, 
followed by teachers with master's or higher degrees. The research results indicated that most of the education service staff had undertaken further education and were constantly seeking to refine their professional skills.

- Teaching experience:

64 participants (27.2\%) had five years of teaching experience or less, 54 participants (23\%) had 6-10 years of teaching experience, 29 participants (12.3\%) had 11-15 years of teaching experience, 34 participants (14.5\%) had 16-20 years of teaching experience, and 54 participants (23\%) had 21 years of teaching experience or more. In terms of teaching experience, teachers with five years of teaching experience or less accounted for the largest percentage of the participants, followed by teachers with 6-10 years of experience, and teachers with 21 years of teaching experience or more. The research results indicated that about half of the participants had served in this field for 10 years or less, demonstrating that education service staff are becoming younger. On the other hand, the participants who had served in this field for more than 10 years also accounted for about half of the participants. This finding corresponded to the research results pertaining to age as a background variable, and showed that many senior teachers are still committed to their roles in preschool education.

- Position:

21 participants $(8.9 \%)$ were substitute teachers, 169 participants $(71.9 \%)$ were teachers, 42 participants $(17.9 \%)$ were teachers with administrative roles, and three participants $(1.3 \%)$ were directors. Teachers accounted for the largest percentage of the participants, followed by teachers with administrative roles. As the participants were teachers, and only teachers managing six or more classes are designated as directors, the proportion of directors was thus the smallest. Given that close to $10 \%$ of the participants were substitute teachers, it is worth examining their influence on the stability of preschool operations and the continuity of teaching depth.

- Teaching model:

six participants (2.6\%) utilized unit teaching, seven participants utilized (3\%) learning zone teaching, 175 participants utilized $(74.5 \%)$ thematic teaching, 16 participants utilized $(6.8 \%)$ project teaching, and 31 participants utilized (12.9\%) other approaches, with 27 participants (11.5\%) utilizing a combination of thematic and learning zone teaching, three participants (1\%) utilizing a combination of unit and thematic teaching, and one participant $(0.4 \%)$ utilizing a combination of learning zone and project teaching. Teachers who utilized thematic teaching accounted for the largest percentage of the participants, followed by those who utilized project teaching. The research results indicated that about $80 \%$ of the participants were utilizing thematic teaching, which emphasizes joint teacher-student exploration and interactions to create a series of learning activities, as in their preschool teaching model. Approximately $10 \%$ of the participants utilized a combination of teaching models, indicating that variability and multi-creativity can be found in preschool teaching.

\subsection{Current State of Integration of Information Technology into Aesthetic Education}

The current state of integration of information technology into aesthetic education involves three constructs: use of aesthetic education activities, teachers' elementary knowledge of information technology, and equipment and administrative resources.

- Use of aesthetic education activities

The mean values of all items in this construct were higher than 3 . The highest mean value was obtained in Item 5, "I use digital information technology (e.g., digital cameras, cameras, mobile phones, etc.) to record learning activities" $(\mathrm{M}=4.42)$, indicating prevailing use of these information technology to record aesthetic education activities among teachers. The second highest mean value was obtained in Item 7, "I use a computer to make records about the teaching process and reflective thoughts" $(\mathrm{M}=4.24)$. Despite the rapid changes in the field of science and technology and constant 
emergence of new digital technologies, teachers mainly apply information technology products familiar to them. The lowest mean value $(<3)$ was obtained in Item 8 , "I use social media (e.g., Facebook, Pinterest, etc.) to discuss and share my educational knowledge and resources with others" $(M=2.74)$, indicating that teachers rarely used social media for this purpose. The results showed that integration of information technology in aesthetic education activities was mainly based on the assistive use of hardware equipment, whereas social media were not often applied in education.

- Teachers' elementary knowledge of information technology

The mean values of all items in this construct were higher than 3, indicating an acceptable level of teachers' information technology knowledge in public preschools in New Taipei City, as well as their willingness to try implementing different forms of information technology in aesthetic education. The highest mean value was obtained in Item 11, "I use the Internet (e.g., IE, Google, etc.) to search for education-related materials" ( $\mathrm{M}=4.73)$, followed by Item 9, "I use basic operational computer software (e.g., Word, PowerPoint, etc.)" $(\mathrm{M}=4.71)$. The results suggested that teachers in public preschools in New Taipei City were familiar with basic operational computer software and possessed basic information literacy and learning capabilities.

\subsection{Equipment and Administrative Resources}

The mean values of all items in this construct were higher than 3, indicating that teachers in public preschools in New Taipei City were provided with sufficient equipment and administrative resources. The highest mean value was obtained in Item 16, "The preschool has sufficient information technology facilities (e.g., computers, projectors, digital cameras, tablets, screens, Internet connection, etc.)" $(\mathrm{M}=4.46)$, followed by Item 17 , “The preschool's information technology facilities are maintained in good state (e.g., regular updates, upgrades, sufficient Internet bandwidth, etc.)" $(\mathrm{M}=4.12)$. The results indicated that most public preschools in New Taipei City provided sufficient equipment for educational use and could maintain it in good state, which helped to fulfil the function of information technology equipment.

As shown in Table 3, the overall mean value of current information technology integration into aesthetic education was 4.10 . The construct with the highest mean value was teachers' elementary knowledge of information technology $(\mathrm{M}=4.52, \mathrm{SD}=0.492)$, indicating teachers' high attention to this aspect in public preschools in New Taipei City; in general, teachers' knowledge of information technology corresponded to the current state of information technology use. The second highest mean value was obtained in the construct of equipment and administrative resources $(M=3.91, S D=0.756)$. The lowest mean value was obtained in the use of aesthetic education activities $(\mathrm{M}=3.88, \mathrm{SD}=0.506)$, indicating that information technology integration into aesthetic education was not common in public preschools in New Taipei City.

Table 3. Analysis of the constructs of information technology integration into aesthetic education.

\begin{tabular}{cccc}
\hline Construct & Items & M & SD \\
\hline Use of aesthetic education activities & $1-8$ & 3.88 & 0.506 \\
\hline Teachers' elementary knowledge of information technology & $9-15$ & 4.52 & 0.492 \\
\hline Equipment and administrative resources & $16-20$ & 3.91 & 0.756 \\
\hline Overall state & & 4.10 & 0.437 \\
\hline
\end{tabular}

\subsection{Aesthetic Education Content Analysis}

- Aesthetic education beliefs

The mean values in all items in this construct were higher than 4, indicating that teachers in public preschools in New Taipei City agreed in their aesthetic education beliefs. The highest mean value was 
obtained in Item 24, "I think that aesthetic education can help children develop their imagination and enjoy self-expression" ( $\mathrm{M}=4.77)$, followed by Item 22 , "I think aesthetic education helps to use five senses to feel different forms of beauty in life" $(\mathrm{M}=4.75)$. The results indicated that teachers in public preschools in New Taipei City paid high attention to aesthetic education's ability to help children use five senses, creativity, and imagination to experience life beauty.

- Aesthetic education practice

As shown in Table 4, the overall mean value of aesthetic education content was 4.50. The construct with the highest mean value was aesthetic education beliefs $(M=4.70, S D=0.398)$, indicating that teachers in public preschools in New Taipei City attached high importance to such beliefs. The aesthetic education practice construct had a lower mean value $(\mathrm{M}=4.30, \mathrm{SD}=0.481)$, indicating that public preschool teachers differed in their actual aesthetic education practice and attention to it.

Table 4. Analysis of the constructs of information technology integration into aesthetic education content.

\begin{tabular}{cccc}
\hline Construct & Items & M & SD \\
\hline Aesthetic education beliefs & $21-28$ & 4.70 & 0.398 \\
\hline Aesthetic education practice & $29-34$ & 4.30 & 0.481 \\
\hline Overall content & & 4.50 & 0.376 \\
\hline
\end{tabular}

5.5. Differences in Information Technology Integration into Aesthetic Education by Teachers with Different Personal Backgrounds

One-way analysis of variance (ANOVA) was used to analyze information technology integration into aesthetic education by teachers with different background variables (age, education level, teaching experience, position, and teaching model) in public preschools in New Taipei City. Differences in overall beliefs and three constructs (current use of aesthetic education activities, teachers' elementary knowledge of information technology, and equipment and administrative resources) were explored.

- Age

According to the ANOVA results presented in Table 5, teachers of different age had no significant differences with regard to the use of aesthetic education activities, elementary knowledge of information technology, and equipment and administrative resources $(P>0.05)$. Thus, teachers of different age working in public preschools in New Taipei City did not differ significantly in their use of aesthetic education activities, elementary knowledge of information technology, and equipment and administrative resources.

- Education Level

According to the ANOVA results presented in Table 6, teachers with different levels of education had no significant differences with regard to the use of aesthetic education activities, elementary knowledge of information technology, and equipment and administrative resources $(P>0.05)$. Thus, teachers with different levels of education working in public preschools in New Taipei City did not differ significantly in their use of aesthetic education activities, elementary knowledge of information technology, and equipment and administrative resources.

- Teaching experience

According to the ANOVA results presented in Table 7, teachers with different levels of teaching experience had no significant differences with regard to the use of aesthetic education activities, elementary knowledge of information technology, and equipment and administrative resources $(P>0.05)$. Thus, teachers with different levels of teaching experience working in public preschools in New Taipei City did not differ significantly in their use of aesthetic education activities, elementary knowledge of information technology, and equipment and administrative resources. 
- Position

According to the ANOVA results presented in Table 8, teachers with different positions had no significant differences with regard to the use of aesthetic education activities, elementary knowledge of information technology, and equipment and administrative resources $(P>0.05)$. Thus, teachers with different positions working in public preschools in New Taipei City did not differ significantly in their use of aesthetic education activities, elementary knowledge of information technology, and equipment and administrative resources.

Table 5. Analysis of differences in information technology integration into aesthetic education depending on teachers' age.

\begin{tabular}{|c|c|c|c|c|c|c|c|}
\hline Construct & $\begin{array}{c}\text { Age } \\
\text { (years) }\end{array}$ & $\mathbf{N}$ & $\mathbf{M}$ & SD & Value & Value & $\begin{array}{c}\text { Post Hoc } \\
\text { Comparison }\end{array}$ \\
\hline \multirow{4}{*}{$\begin{array}{c}\text { Use of aesthetic } \\
\text { education activities }\end{array}$} & $\leq 30$ & 61 & 3.89 & 0.421 & \multirow{4}{*}{0.393} & \multirow{4}{*}{0.675} & \\
\hline & $31-40$ & 75 & 3.91 & 0.504 & & & \\
\hline & $\geq 41$ & 99 & 3.84 & 0.556 & & & \\
\hline & Total & 235 & 3.88 & 0.506 & & & \\
\hline \multirow{4}{*}{$\begin{array}{l}\text { Teachers' elementary } \\
\text { knowledge of } \\
\text { information } \\
\text { technology }\end{array}$} & $\leq 30$ & 61 & 4.55 & 0.424 & \multirow{4}{*}{1.308} & \multirow{4}{*}{0.272} & \\
\hline & $31-40$ & 75 & 4.58 & 0.435 & & & \\
\hline & $\geq 41$ & 99 & 4.46 & 0.564 & & & \\
\hline & Total & 235 & 4.52 & 0.492 & & & \\
\hline \multirow{4}{*}{$\begin{array}{l}\text { Equipment and } \\
\text { administrative } \\
\text { resources }\end{array}$} & $\leq 30$ & 61 & 3.84 & 0.661 & \multirow{4}{*}{2.093} & \multirow{4}{*}{0.126} & \\
\hline & $31-40$ & 75 & 3.81 & 0.753 & & & \\
\hline & $\geq 41$ & 99 & 4.03 & 0.802 & & & \\
\hline & Total & 235 & 3.91 & 0.756 & & & \\
\hline
\end{tabular}

Table 6. Analysis of differences in information technology integration into aesthetic education depending on teachers' education level.

\begin{tabular}{|c|c|c|c|c|c|c|c|}
\hline Construct & Education Level & $\mathbf{N}$ & $\mathbf{M}$ & SD & F-Value & $p$-Value & $\begin{array}{l}\text { Post Hoc } \\
\text { Comparison }\end{array}$ \\
\hline \multirow{4}{*}{$\begin{array}{l}\text { Use of aesthetic } \\
\text { education } \\
\text { activities }\end{array}$} & Master's degree or higher & 82 & 3.93 & 0.537 & \multirow{4}{*}{0.653} & \multirow{4}{*}{0.521} & \\
\hline & $\begin{array}{l}\text { Qualification obtained through a } \\
\text { general university's teacher } \\
\text { education program }\end{array}$ & 50 & 3.86 & 0.525 & & & \\
\hline & $\begin{array}{l}\text { Qualification from a teacher's } \\
\text { college or university of education }\end{array}$ & 103 & 3.85 & 0.472 & & & \\
\hline & Total & 235 & 3.88 & 0.506 & & & \\
\hline \multirow{4}{*}{$\begin{array}{l}\text { Teachers' } \\
\text { elementary } \\
\text { knowledge of } \\
\text { information } \\
\text { technology }\end{array}$} & Master's degree or higher & 82 & 4.56 & 0.443 & \multirow{4}{*}{0.353} & \multirow{4}{*}{0.703} & \\
\hline & $\begin{array}{l}\text { Qualification obtained through a } \\
\text { general university's teacher } \\
\text { education program }\end{array}$ & 50 & 4.52 & 0.500 & & & \\
\hline & $\begin{array}{l}\text { Qualification from a teacher's } \\
\text { college or university of education }\end{array}$ & 103 & 4.50 & 0.526 & & & \\
\hline & Total & 235 & 4.52 & 0.492 & & & \\
\hline \multirow{4}{*}{$\begin{array}{l}\text { Equipment and } \\
\text { administrative } \\
\text { resources }\end{array}$} & Master's degree or higher & 82 & 3.94 & 0.801 & \multirow{4}{*}{0.130} & \multirow{4}{*}{0.878} & \\
\hline & $\begin{array}{l}\text { Qualification obtained through a } \\
\text { general university's teacher } \\
\text { education program }\end{array}$ & 50 & 3.90 & 0.700 & & & \\
\hline & $\begin{array}{l}\text { Qualification from a teacher's } \\
\text { college or university of education }\end{array}$ & 103 & 3.88 & 0.751 & & & \\
\hline & Total & 235 & 3.91 & 0.756 & & & \\
\hline
\end{tabular}


Table 7. Analysis of differences in information technology integration into aesthetic education depending on teachers' teaching experience.

\begin{tabular}{|c|c|c|c|c|c|c|c|}
\hline Construct & $\begin{array}{c}\text { Teaching } \\
\text { Experience (Years) }\end{array}$ & $\mathbf{N}$ & $\mathbf{M}$ & SD & F-Value & $p$-Value & $\begin{array}{c}\text { Post Hoc } \\
\text { Comparison }\end{array}$ \\
\hline \multirow{6}{*}{$\begin{array}{l}\text { Use of aesthetic } \\
\text { education } \\
\text { activities }\end{array}$} & $\leq 5$ & 64 & 3.86 & 0.385 & \multirow{6}{*}{0.635} & \multirow{6}{*}{0.638} & \\
\hline & $6-10$ & 54 & 3.92 & 0.479 & & & \\
\hline & $11-15$ & 29 & 3.84 & 0.606 & & & \\
\hline & $16-20$ & 34 & 3.97 & 0.476 & & & \\
\hline & $\geq 21$ & 54 & 3.82 & 0.615 & & & \\
\hline & Total & 235 & 3.88 & 0.506 & & & \\
\hline \multirow{6}{*}{$\begin{array}{c}\text { Teachers' } \\
\text { elementary } \\
\text { knowledge of } \\
\text { information } \\
\text { technology }\end{array}$} & $\leq 5$ & 64 & 4.55 & 0.436 & \multirow{6}{*}{0.407} & \multirow{6}{*}{0.804} & \\
\hline & $6-10$ & 54 & 4.57 & 0.435 & & & \\
\hline & $11-15$ & 29 & 4.47 & 0.480 & & & \\
\hline & $16-20$ & 34 & 4.52 & 0.458 & & & \\
\hline & $\geq 21$ & 54 & 4.48 & 0.626 & & & \\
\hline & Total & 235 & 4.52 & 4.92 & & & \\
\hline \multirow{6}{*}{$\begin{array}{l}\text { Equipment and } \\
\text { administrative } \\
\text { resources }\end{array}$} & $\leq 5$ & 64 & 3.85 & 0.759 & \multirow{6}{*}{1.67} & \multirow{6}{*}{0.158} & \\
\hline & $6-10$ & 54 & 3.81 & 0.648 & & & \\
\hline & $11-15$ & 29 & 3.78 & 0.776 & & & \\
\hline & $16-20$ & 34 & 3.94 & 0.794 & & & \\
\hline & $\geq 21$ & 54 & 4.12 & 0.797 & & & \\
\hline & Total & 235 & 3.91 & 0.756 & & & \\
\hline
\end{tabular}

Table 8. Analysis of differences in information technology integration into aesthetic education depending on teachers' positions.

\begin{tabular}{|c|c|c|c|c|c|c|c|}
\hline Construct & Position & $\mathbf{N}$ & $\mathbf{M}$ & SD & F-Value & $p$-Value & $\begin{array}{l}\text { Post hoc } \\
\text { Comparison }\end{array}$ \\
\hline \multirow{5}{*}{$\begin{array}{l}\text { Use of aesthetic } \\
\text { education } \\
\text { activities }\end{array}$} & Substitute teacher & 21 & 3.92 & 0.489 & \multirow{5}{*}{0.066} & \multirow{5}{*}{0.978} & \\
\hline & Teacher & 169 & 3.87 & 0.525 & & & \\
\hline & $\begin{array}{l}\text { Teacher with } \\
\text { administrative role }\end{array}$ & 42 & 3.88 & 0.464 & & & \\
\hline & Director & 3 & 3.91 & 0.144 & & & \\
\hline & Total & 235 & 3.88 & 0.506 & & & \\
\hline \multirow{5}{*}{$\begin{array}{l}\text { Teachers' } \\
\text { elementary } \\
\text { knowledge of } \\
\text { information } \\
\text { technology }\end{array}$} & Substitute teacher & 21 & 4.55 & 0.456 & \multirow{5}{*}{1.159} & \multirow{5}{*}{0.325} & \\
\hline & Teacher & 169 & 4.50 & 0.520 & & & \\
\hline & $\begin{array}{l}\text { Teacher with } \\
\text { administrative role }\end{array}$ & 42 & 4.64 & 0.369 & & & \\
\hline & Director & 3 & 4.33 & 0.501 & & & \\
\hline & Total & 235 & 4.52 & 0.492 & & & \\
\hline \multirow{5}{*}{$\begin{array}{l}\text { Equipment and } \\
\text { administrative } \\
\text { resources }\end{array}$} & Substitute teacher & 21 & 4.19 & 0.658 & \multirow{5}{*}{1.069} & \multirow{5}{*}{0.363} & \\
\hline & Teacher & 169 & 3.87 & 0.748 & & & \\
\hline & $\begin{array}{l}\text { Teacher with } \\
\text { administrative role }\end{array}$ & 42 & 3.91 & 0.841 & & & \\
\hline & Director & 3 & 3.86 & 0.230 & & & \\
\hline & Total & 235 & 3.91 & 0.756 & & & \\
\hline
\end{tabular}


- Teaching model

According to the ANOVA results presented in Table 9, teachers using different teaching models had significant differences with regard to the use of aesthetic education activities, elementary knowledge of information technology, and equipment and administrative resources $(P<0.05)$. However, pairwise comparisons using Scheffe's method showed that teachers using different teaching models in public preschools in New Taipei City did not differ significantly in their use of aesthetic education activities, elementary knowledge of information technology, and equipment and administrative resources.

Table 9. Analysis of differences in information technology integration into aesthetic education depending on teachers' teaching model.

\begin{tabular}{|c|c|c|c|c|c|c|c|}
\hline Construct & Teaching Model & $\mathbf{N}$ & $\mathbf{M}$ & SD & F-Value & $p$-Value & $\begin{array}{l}\text { Post Hoc } \\
\text { Comparison }\end{array}$ \\
\hline \multirow{6}{*}{$\begin{array}{l}\text { Use of } \\
\text { aesthetic } \\
\text { education } \\
\text { activities }\end{array}$} & Unit teaching & 6 & 3.54 & 0.170 & \multirow{6}{*}{2.464 * } & \multirow{6}{*}{0.046} & \multirow{6}{*}{ N.S. } \\
\hline & Learning zone teaching & 7 & 3.48 & 0.761 & & & \\
\hline & Thematic teaching & 175 & 3.90 & 0.493 & & & \\
\hline & Project teaching & 16 & 4.04 & 0.580 & & & \\
\hline & Other & 31 & 3.82 & 0.465 & & & \\
\hline & Total & 235 & 3.88 & 0.506 & & & \\
\hline \multirow{6}{*}{$\begin{array}{l}\text { Teachers' } \\
\text { elementary } \\
\text { knowledge of } \\
\text { information } \\
\text { technology }\end{array}$} & Unit teaching & 6 & 4.80 & 0.173 & \multirow{6}{*}{$2.806^{*}$} & \multirow{6}{*}{0.027} & \multirow{6}{*}{ N.S. } \\
\hline & Learning zone teaching & 7 & 4.00 & 0.853 & & & \\
\hline & Thematic teaching & 175 & 4.54 & 0.492 & & & \\
\hline & Project teaching & 16 & 4.59 & 0.376 & & & \\
\hline & Other & 31 & 4.47 & 0.417 & & & \\
\hline & Total & 235 & 4.52 & 0.492 & & & \\
\hline \multirow{6}{*}{$\begin{array}{l}\text { Equipment } \\
\text { and } \\
\text { administrative } \\
\text { resources }\end{array}$} & Unit teaching & 6 & 3.10 & 0.629 & \multirow{6}{*}{$2.554 *$} & \multirow{6}{*}{0.040} & \multirow{6}{*}{ N.S. } \\
\hline & Learning zone teaching & 7 & 3.65 & 0.772 & & & \\
\hline & Thematic teaching & 175 & 3.96 & 0.757 & & & \\
\hline & Project teaching & 16 & 4.01 & 0.617 & & & \\
\hline & Other & 31 & 3.77 & 0.753 & & & \\
\hline & Total & 235 & 3.91 & 0.756 & & & \\
\hline
\end{tabular}

5.6. Differences in Information Technology Integration into Aesthetic Education Content by Teachers with Different Personal Backgrounds

ANOVA was used to analyze differences in information technology integration into aesthetic education content (aesthetic education beliefs, aesthetic education practice, and overall content) by teachers with different background variables (age, education level, teaching experience, position, and teaching model) in public preschools in New Taipei City.

- Age

According to the ANOVA results presented in Table 10, teachers of different ages had no significant differences in their aesthetic education beliefs and aesthetic education practice $(P>0.05)$. Thus, teachers of different ages working in public preschools in New Taipei City did not differ significantly in their aesthetic education beliefs and aesthetic education practice. 
Table 10. Analysis of differences in information technology integration into aesthetic education content depending on teachers' age.

\begin{tabular}{|c|c|c|c|c|c|c|c|}
\hline Construct & $\begin{array}{c}\text { Age } \\
\text { (Years) }\end{array}$ & $\mathbf{N}$ & $\mathbf{M}$ & SD & F-Value & $p$-Value & $\begin{array}{c}\text { Post Hoc } \\
\text { Comparison }\end{array}$ \\
\hline \multirow{4}{*}{$\begin{array}{c}\text { Aesthetic } \\
\text { education } \\
\text { beliefs }\end{array}$} & $\leq 30$ & 61 & 4.70 & 0.383 & \multirow{4}{*}{0.426} & \multirow{4}{*}{0.653} & \\
\hline & $31-40$ & 75 & 4.67 & 0.435 & & & \\
\hline & $\geq 41$ & 99 & 4.72 & 0.380 & & & \\
\hline & Total & 235 & 4.70 & 0.398 & & & \\
\hline \multirow{4}{*}{$\begin{array}{l}\text { Aesthetic } \\
\text { education } \\
\text { practice }\end{array}$} & $\leq 30$ & 61 & 4.20 & 0.440 & \multirow{4}{*}{1.737} & \multirow{4}{*}{0.178} & \\
\hline & $31-40$ & 75 & 4.32 & 0.506 & & & \\
\hline & $\geq 41$ & 99 & 4.34 & 0.482 & & & \\
\hline & Total & 235 & 4.30 & 0.481 & & & \\
\hline
\end{tabular}

- Education level

According to the ANOVA results presented in Table 11, teachers with different education levels had no significant differences in their aesthetic education beliefs and aesthetic education practice $(P>0.05)$. Thus, teachers with different education levels working in public preschools in New Taipei City did not differ significantly in their aesthetic education beliefs and aesthetic education practice.

Table 11. Analysis of differences in information technology integration into aesthetic education content depending on teachers' education level.

\begin{tabular}{|c|c|c|c|c|c|c|c|}
\hline Construct & Education Level & $\mathbf{N}$ & $\mathbf{M}$ & SD & F-Value & $p$-Value & $\begin{array}{l}\text { Post Hoc } \\
\text { Comparison }\end{array}$ \\
\hline \multirow{4}{*}{$\begin{array}{l}\text { Aesthetic } \\
\text { education } \\
\text { beliefs }\end{array}$} & Master's degree or higher & 82 & 4.68 & 0.427 & \multirow{4}{*}{0.168} & \multirow{4}{*}{0.845} & \\
\hline & $\begin{array}{l}\text { Qualification obtained through a } \\
\text { general university's teacher } \\
\text { education program }\end{array}$ & 50 & 4.69 & 0.395 & & & \\
\hline & $\begin{array}{l}\text { Qualification from a teacher's } \\
\text { college or university of education }\end{array}$ & 103 & 4.72 & 0.378 & & & \\
\hline & Total & 235 & 4.70 & 0.398 & & & \\
\hline \multirow{4}{*}{$\begin{array}{l}\text { Aesthetic } \\
\text { education } \\
\text { practice }\end{array}$} & Master's degree or higher & 82 & 4.36 & 0.513 & \multirow{4}{*}{1.48} & \multirow{4}{*}{0.229} & \\
\hline & $\begin{array}{l}\text { Qualification obtained through a } \\
\text { general university's teacher } \\
\text { education program }\end{array}$ & 50 & 4.21 & 0.409 & & & \\
\hline & $\begin{array}{l}\text { Qualification from a teacher's } \\
\text { college or university of education }\end{array}$ & 103 & 4.30 & 0.485 & & & \\
\hline & Total & 235 & 4.30 & 0.481 & & & \\
\hline
\end{tabular}

\section{- Teaching experience}

According to the ANOVA results presented in Table 12, teachers with different levels of teaching experience had no significant differences in their aesthetic education beliefs and aesthetic education practice $(P>0.05)$. Thus, teachers with different levels of teaching experience working in public preschools in New Taipei City did not differ significantly in their aesthetic education beliefs and aesthetic education practice. 
Table 12. Analysis of differences in information technology integration into aesthetic education content depending on teachers' teaching experience.

\begin{tabular}{|c|c|c|c|c|c|c|c|}
\hline Construct & $\begin{array}{c}\text { Teaching } \\
\text { Experience (Years) }\end{array}$ & $\mathbf{N}$ & $\mathbf{M}$ & SD & F-Value & $p$-Value & $\begin{array}{c}\text { Post Hoc } \\
\text { Comparison }\end{array}$ \\
\hline \multirow{6}{*}{$\begin{array}{c}\text { Aesthetic } \\
\text { education } \\
\text { beliefs }\end{array}$} & $\leq 5$ years & 64 & 4.68 & 0.394 & \multirow{6}{*}{1.917} & \multirow{6}{*}{0.108} & \\
\hline & $6-10$ years & 54 & 4.76 & 0.342 & & & \\
\hline & $11-15$ years & 29 & 4.54 & 0.505 & & & \\
\hline & $16-20$ years & 34 & 4.78 & 0.363 & & & \\
\hline & $\geq 21$ years & 54 & 4.70 & 0.398 & & & \\
\hline & Total & 235 & 4.70 & 0.398 & & & \\
\hline \multirow{6}{*}{$\begin{array}{l}\text { Aesthetic } \\
\text { education } \\
\text { practice }\end{array}$} & $\leq 5$ years & 64 & 4.27 & 0.435 & \multirow{6}{*}{1.031} & \multirow{6}{*}{0.392} & \\
\hline & 6-10 years & 54 & 4.31 & 0.462 & & & \\
\hline & 11-15 years & 29 & 4.21 & 0.597 & & & \\
\hline & $16-20$ years & 34 & 4.44 & 0.472 & & & \\
\hline & $\geq 21$ years & 54 & 4.30 & 0.487 & & & \\
\hline & Total & 235 & 4.30 & 0.481 & & & \\
\hline
\end{tabular}

- Position

According to the ANOVA results presented in Table 13, teachers with different positions had no significant differences in their aesthetic education beliefs and aesthetic education practice $(P>0.05)$. Thus, teachers with different positions working in public preschools in New Taipei City did not differ significantly in their aesthetic education beliefs and aesthetic education practice.

Table 13. Analysis of differences in information technology integration into aesthetic education content depending on teachers' positions.

\begin{tabular}{|c|c|c|c|c|c|c|c|}
\hline Construct & Position & $\mathbf{N}$ & $\mathbf{M}$ & SD & F-Value & $p$-Value & $\begin{array}{c}\text { Post Hoc } \\
\text { Comparison }\end{array}$ \\
\hline \multirow{5}{*}{$\begin{array}{l}\text { Aesthetic } \\
\text { education } \\
\text { beliefs }\end{array}$} & Substitute teacher & 21 & 4.82 & 0.257 & \multirow{5}{*}{0.777} & \multirow{5}{*}{0.508} & \\
\hline & Teacher & 169 & 4.69 & 0.414 & & & \\
\hline & $\begin{array}{l}\text { Teacher with } \\
\text { administrative role }\end{array}$ & 42 & 4.69 & 0.396 & & & \\
\hline & Director & 3 & 4.83 & 0.288 & & & \\
\hline & Total & 235 & 4.70 & 0.398 & & & \\
\hline \multirow{5}{*}{$\begin{array}{l}\text { Aesthetic } \\
\text { education } \\
\text { practice }\end{array}$} & Substitute teacher & 21 & 4.34 & 0.406 & \multirow{5}{*}{0.104} & \multirow{5}{*}{0.958} & \\
\hline & Teacher & 169 & 4.30 & 0.509 & & & \\
\hline & $\begin{array}{l}\text { Teacher with } \\
\text { administrative role }\end{array}$ & 42 & 4.27 & 0.419 & & & \\
\hline & Director & 3 & 4.27 & 0.254 & & & \\
\hline & Total & 235 & 4.30 & 0.481 & & & \\
\hline
\end{tabular}

- Teaching model

According to the ANOVA results presented in Table 14, teachers using different teaching models had no significant differences in their aesthetic education beliefs and aesthetic education practice $(P>0.05)$. Thus, teachers using different teaching models in public preschools in New Taipei City did not differ significantly in their aesthetic education beliefs and aesthetic education practice. 
Table 14. Analysis of differences in information technology integration into aesthetic education content depending on teachers' teaching model.

\begin{tabular}{|c|c|c|c|c|c|c|c|}
\hline Construct & Teaching Model & $\mathbf{N}$ & $\mathbf{M}$ & SD & F-Value & $p$-Value & $\begin{array}{c}\text { Post Hoc } \\
\text { Comparison }\end{array}$ \\
\hline \multirow{6}{*}{$\begin{array}{l}\text { Aesthetic } \\
\text { education } \\
\text { beliefs }\end{array}$} & Unit teaching & 6 & 4.77 & 0.406 & \multirow{6}{*}{0.080} & \multirow{6}{*}{0.988} & \\
\hline & $\begin{array}{l}\text { Learning zone } \\
\text { teaching }\end{array}$ & 7 & 4.71 & 0.295 & & & \\
\hline & Thematic teaching & 175 & 4.70 & 0.405 & & & \\
\hline & Project teaching & 16 & 4.71 & 0.381 & & & \\
\hline & Other & 31 & 4.67 & 0.404 & & & \\
\hline & Total & 235 & 4.70 & 0.398 & & & \\
\hline \multirow{6}{*}{$\begin{array}{l}\text { Aesthetic } \\
\text { education } \\
\text { practice }\end{array}$} & Unit teaching & 6 & 4.13 & 0.356 & \multirow{6}{*}{0.433} & \multirow{6}{*}{0.785} & \\
\hline & $\begin{array}{l}\text { Learning zone } \\
\text { teaching }\end{array}$ & 7 & 4.28 & 0.566 & & & \\
\hline & Thematic teaching & 175 & 4.32 & 0.494 & & & \\
\hline & Project teaching & 16 & 4.26 & 0.482 & & & \\
\hline & Other & 31 & 4.24 & 0.421 & & & \\
\hline & Total & 235 & 4.30 & 0.481 & & & \\
\hline
\end{tabular}

Integration of information technology into aesthetic education by teachers in public preschools in New Taipei City.

\subsection{Analysis of Correlation between Current State and Aesthetic Education Content}

Pearson correlation analysis was performed to explore the correlation between the current state of information technology integration into aesthetic education (including the use of aesthetic education activities, teachers' elementary knowledge of information technology, and equipment and administrative resources) and aesthetic education content (including aesthetic education beliefs and aesthetic education practice). A Pearson correlation coefficient approaching 1 indicated strong correlation.

As shown in Table 15, teachers' aesthetic education beliefs were positively and significantly correlated with the use of aesthetic education activities, elementary knowledge of information technology, equipment and administrative resources, and overall integration of information technology into aesthetic education $\left(r=0.261^{* *}, P<0.01 ; r=0.467^{* *}, P<0.01 ; r=0.264^{* *}, P<0.01 ; r=0.427^{* *}\right.$, $P<0.01)$. Thus, teachers who approved aesthetic education beliefs were more likely to engage in behaviors related to the use of aesthetic education activities, elementary knowledge of information technology, equipment and administrative resources, and overall integration of information technology into aesthetic education.

Teachers' aesthetic education practice was positively and significantly correlated with the use of aesthetic education activities, elementary knowledge of information technology, equipment and administrative resources, and overall integration of information technology into aesthetic education $\left(r=0.560^{* *}, P<0.01 ; r=0.481^{* *}, P<0.01 ; r=0.309^{* *}, P<0.01 ; r=0.574^{* *}, P<0.01\right)$. Thus, teachers who often engaged in aesthetic education practice were more likely to engage in behaviors related to the use of aesthetic education activities, elementary knowledge of information technology, equipment and administrative resources, and overall integration of information technology into aesthetic education.

Teachers' overall aesthetic education content was positively and significantly correlated with the use of aesthetic education activities, elementary knowledge of information technology, equipment and administrative resources, and overall integration of information technology into aesthetic education $\left(r=0.496^{* *}, P<0.01 ; r=0.554^{* *}, P<0.01 ; r=0.337^{* *}, P<0.01 ; r=0.593^{* *}, P<0.01\right)$. Thus, teachers who approved and often engaged in behaviors related to overall aesthetic education content were more likely to engage in behaviors related to the use of aesthetic education activities, elementary 
knowledge of information technology, equipment and administrative resources, and overall integration of information technology into aesthetic education.

Table 15. Product moment correlation between integration of information technology into aesthetic education and aesthetic education content.

\begin{tabular}{ccccc}
\hline \multirow{2}{*}{$\begin{array}{c}\text { Aesthetic Education } \\
\text { Content }\end{array}$} & \multicolumn{2}{c}{ Current State of Integration of Information Technology into Aesthetic Education } \\
\cline { 2 - 5 } & $\begin{array}{c}\text { Use of Aesthetic } \\
\text { Education } \\
\text { Activities }\end{array}$ & $\begin{array}{c}\text { Teachers' Elementary } \\
\text { Knowledge of } \\
\text { Information Technology }\end{array}$ & $\begin{array}{c}\text { Equipment and } \\
\text { Administrative } \\
\text { Resources }\end{array}$ & Total \\
\hline $\begin{array}{c}\text { Aesthetic education } \\
\text { beliefs }\end{array}$ & $0.261^{* *}$ & $0.467^{* *}$ & $0.264^{* *}$ & $0.427^{* *}$ \\
\hline $\begin{array}{c}\text { Aesthetic education } \\
\text { practice }\end{array}$ & $0.560^{* *}$ & $0.481^{* *}$ & $0.309^{* *}$ & $0.574^{* *}$ \\
\hline Total & $0.496^{* *}$ & $0.554^{* *}$ & $0.337^{* *}$ & $0.593^{* *}$ \\
\hline
\end{tabular}

Table 15 shows the presence of correlations between all the constructs of aesthetic education content and information technology integration into aesthetic education, with the most significant correlations observed between aesthetic education content and teachers' elementary knowledge of information technology $\left(r=0.554^{* *}\right)$, followed by the use of aesthetic education activities $\left(r=0.496^{* *}\right)$ and equipment and administrative resources $\left(r=0.337^{* *}\right)$. Hence, teachers' elementary knowledge of information technology was significantly and positively correlated with aesthetic education content factors.

\section{Conclusions}

Aesthetic education content are discussed first. Afterward, current state of information technology integration into aesthetic education and aesthetic education content factors were summarized and discussed.

\subsection{Background Characteristics of Teachers in Public Preschools in New Taipei City, Current State of Information Technology Integration into Aesthetic Education, and Aesthetic Education Content}

(a) Background characteristics of teachers in public preschools in New Taipei City

Most participants belonged to the age group of 41 years and older, had graduated from a teacher's college or university of education, had five years of teaching experience or less, held the position of a teacher and applied the thematic teaching model. Thus, most teachers in public preschools in New Taipei City belong to an older age group and have five years of teaching experience or less. The Department of Education, New Taipei City Government, holds annual entrance examinations for new teachers, among whom young teachers account for a large proportion.

(b) Current state of information technology integration into aesthetic education

A major construct related to the current state of information technology integration into aesthetic education was teachers' elementary knowledge of information technology, indicating that most teachers in public preschools in New Taipei City corresponded to the actual situation in terms of their knowledge and attached high importance to it. The second major construct was equipment and administrative resources, indicating that most preschools had sufficient equipment and administrative resources. The use of aesthetic education activities was the least significant construct, suggesting that teachers in public preschools in New Taipei City did not often use information technology in aesthetic education activities. Furthermore, the highest standard deviation value was obtained in equipment and administrative resources, indicating large differences in this construct, which could be related to overall information technology equipment planning in each preschool. The second highest standard 
deviation value was obtained in the use of aesthetic education activities, suggesting that such use was a matter of a habit, for which reason teachers in public preschools differed from one another.

(c) Current state of aesthetic education content

A major construct in aesthetic education content was aesthetic education beliefs, indicating that teachers in public preschools in New Taipei City attached high importance to this aspect. A less significant construct was aesthetic education practice, meaning that teachers in public preschools in New Taipei City attached less importance to it and did not often engage in related behaviors. Aesthetic education practice was characterized by the largest standard deviation value, indicating large differences in this construct. Thus, teachers in public preschools in New Taipei City performed differently in this construct. With regard to the background characteristics of teachers in public preschools in New Taipei City and information technology integration into aesthetic education, teachers of different ages, with different education levels, with different levels of teaching experience, with different positions, and using different teaching models did not differ significantly in terms of their overall integration of information technology into aesthetic education. This study showed that teachers with different background characteristics did not differ significantly in terms of information technology integration into aesthetic education. No significant differences were observed in the use of aesthetic education activities, elementary knowledge of information technology, and equipment and administrative resources. Hence, teachers in public preschools in New Taipei City had similar performance in terms of their use of aesthetic education activities, elementary knowledge of information technology, and equipment and administrative resources. Public preschools in New Taipei City had a similar level of information technology learning equipment and environment, as well as teachers' elementary knowledge of information technology, and provided sufficient information technology hardware for use in aesthetic education activities, teaching content, and record of children's learning performance. This study's findings related to teachers' age and education level corresponded to the results reported by Chou (2013) [27] but differed from those reported by Tan and Hsu (2018) [7] suggesting that there are regional differences in information technology equipment and environment in New Taipei City and Penghu.

\subsection{Background Variables of Teachers in Public Preschools in New Taipei City and Differences in Aesthetic Education Content}

Teachers of different ages, with different education levels, with different levels of teaching experience, with different positions, and using different teaching models were found to have no significant differences in overall aesthetic education content.

This study found that teachers with different background characteristics did not differ significantly in terms of overall aesthetic education content. No significant differences were observed in the two constructs, aesthetic education beliefs and aesthetic education practice. Thus, teachers in public preschools in New Taipei City had similar performance in terms of aesthetic education beliefs and aesthetic education practice. They had a similar level of aesthetic education ideas and understanding and believed that aesthetic education guides children in using their five senses, experiencing life, developing imagination and engaging in creativity. Integration of teaching concepts in aesthetic education activities can enrich children's aesthetic experiences.

The relations between three constructs of information technology integration into aesthetic education and two constructs of aesthetic education content are explained below.

In terms of aesthetic education in preschools, the implementation of related information technology is less applicable since children in most New Taipei City preschool classes are of different ages, making it difficult to consider the appropriate teaching content. Furthermore, the purchase of information technology for every class may not always be a preschool's funding priority.

(a). Significant positive correlation between the use of aesthetic education activities and aesthetic education content factors 
Teachers' use of aesthetic education activities was found to be related to aesthetic education beliefs and aesthetic education practice. Thus, teachers who often integrated information technology in aesthetic education activities were more likely to approve of the ideas related to aesthetic education beliefs and aesthetic education practice.

(b). Significant positive correlation between teachers' elementary knowledge of information technology and aesthetic education content factors

Teachers' elementary knowledge of information technology was found to be related to aesthetic education beliefs and aesthetic education practice. Thus, teachers who often integrated information technology in aesthetic education activities were more likely to approve of the ideas related to aesthetic education beliefs and aesthetic education practice.

\subsection{Significant Positive Correlation between Equipment and Administrative Resources and Aesthetic Education Content Factors.}

Teachers' equipment and administrative resources were found to be related to aesthetic education beliefs and aesthetic education practice. Thus, teachers who often integrated information technology in aesthetic education activities were more likely to approve of the ideas related to aesthetic education beliefs and aesthetic education practice.

\subsection{Significant Positive Correlation between the Current State of Information Technology Integration into Aesthetic Education and Aesthetic Education Content Factors}

All constructs of information technology integration into aesthetic education were found to be significantly and positively correlated with aesthetic education content factors. The most significant correlation was observed between the use of aesthetic education activities and aesthetic education practice, followed by correlations between teachers' elementary knowledge of information technology and aesthetic education practice, teachers' elementary knowledge of information technology and aesthetic education beliefs, equipment and administrative resources and aesthetic education practice, equipment and administrative resources and aesthetic education beliefs, and, finally, use of aesthetic education activities and aesthetic education beliefs. Thus, current state of information technology integration into aesthetic education is significantly and positive correlated with aesthetic education practice.

Currently, most preschool teachers in Taiwan are primarily professionals who specialize in early childhood education. Therefore, they may know about the application of information technology in education, but are not necessarily adept at it. Moreover, due to the requirements of education units, some teachers have taken an interest in attending short-term learning courses on the implementation of information technology. While the constructs of aesthetic education in New Taipei City are focused on getting children to observe and develop affections for their surroundings, this study was conducted in the hope that a better understanding of general trends and an improved level of knowledge and competency regarding related information technology can be achieved through our early childhood education.

Suggestions and implications for practice:

A. The integration of information technology into education is a good approach to promote the development of each preschooler, but its implementation is subjected to various considerations.

B. Aesthetic education can be used to emphasize the development of the right (artistic) hemisphere of the human brain, especially with regard to innovative and creative abilities, as such development is different from the development of the left (objective) hemisphere.

C. The knowledge and implementation of general information technology in Taiwanese preschool teachers should be enhanced.

D. This study investigated the current status of the implementation of information technology in aesthetic education by New Taipei City preschool teachers. It is hoped that this study is beneficial for future researchers conducting similar investigations. 


\subsection{The Contributions of This Study}

- This study emphasized that a foundation for one-city one-life sustainable learning in aesthetic education must be actively established in preschool education. Children must be exposed to in-depth learning and appreciation of aesthetic elements of people, events, and objects.

- Preschool teachers are encouraged to use information technology in children's learning in order to deepen and broaden education and expand children's horizons.

Author Contributions: Writing—original draft, R.-J.D.F.; Writing—review \& editing, P.J.B.T.

Funding: This research received no external funding.

Conflicts of Interest: The authors declare no conflict of interest.

\section{References}

1. Space in School and ESD: A Study on Integrating Education for Sustainable Development in Planning and Designing Space in School. Available online: http://www.nhu.edu.tw/ \{\}envart/learning/10/10_02.pdf (accessed on 21 February 2019).

2. Tilbury, D.; Goldstein, W. What is ESD? An Overview. Retrieved in 1 February, 2008. Available online: http://cec. wcln.org/index.php? module=pagesetter\&func=viewpub\&tid=15\&pid=67 (accessed on 21 February 2019).

3. UNESCO (2007) Highlights on DESD Progress to Date. Retrieved 1 February, 2008. Available online: http://www.unesco-sweden.org/shared/pdf/\%C3\%85rtionderapport\%20APRIL07.pdf (accessed on 23 February 2019).

4. John Dewey Biography. Available online: https://www.enotes.com/topics/john-dewey (accessed on 1 April 2019).

5. Theisens, H.; Benavides, F; Dumont, H. OECD Work on Future Educational Environments. OCED 2008, 10, 1-10.

6. Early Childhood Safety Education Center. Available online: http://www.wfc.edu.tw/ecsec/about.php (accessed on 21 February 2019).

7. Tan, P.J.B.; Hsu, M.H. Designing a system for English evaluation and teaching devices A PZB and TAM model analysis. Euraia J. Math. Sci. Technol. Educ. 2018, 14, 2107-2119.

8. Papadakis, S.J.; Kalogiannakis, M. Mobile educational applications for children. What educators and parents need to know. Int. J. Mob. Learn. Organ. 2017, 11, 256-277. [CrossRef]

9. Tan, P.J.B. Applying the UTAUT to understand factor affecting the use of English E-learning websites in Taiwan. Sage Open 2013. [CrossRef]

10. Eryilmaz, S.; Adalar, H.; Icinak, A. E-Learning as a teaching strategy actively used in FATIH Project. Eur. J. Educ. Res. 2015, 4, 38-47. [CrossRef]

11. Keller, J. The systematic process of motivational design. Perform. Instr. 1987, 26, 1-8. [CrossRef]

12. Malone, T.W.; Lepper, M.R. Making learning fun: A taxonomy of intrinsic motivations for learning. In Aptitude, Learning, and Instruction: Cognative and Affective Process Analysis; Snow, R.E., Farr, M.J., Eds.; Erlbaum: Hillsdale, NJ, USA, 1987; Volume 3, pp. 223-253.

13. Riaz, S.; Rambli, D.R.A.; Salleh, R.; Mushtaq, A. Exploratory Factor Analysis (EFA) to Examine Learner's Aesthetic Perceptions and Motivation through their Aesthetic-Emotions in Informal Visual Environments. Inf. Technol. J. 2011, 10, 1268-1284. [CrossRef]

14. Kalogiannakis, M.; Ampartzaki, M.; Papadakis, S.J.; Skaraki, E. Teaching Natural Science Concepts to Young Children with Mobile Devices and Hands-on Activities. A Case Study. Int. J. Teach. C Stud. 2018, 9, 171-183. [CrossRef]

15. Wright, S. Why Art Is Important for Young Children: The Arts, Young Children, and Learning; Pearson: London, UK, 2003.

16. Nikolopoulou, K.; Gialamas, V. Investigating pre-service early childhood teachers' views and intentions about integrating and using computers in early childhood settings: Compilation of an instrument. Technol. Pedagog. Educ. 2009, 18, 201-219. [CrossRef] 
17. Tao, Y.H.; Cheng, C.J.; Sun, S.Y. What influences college students to continue using business simulation games? The Taiwan experience. Comput. Educ. 2009, 53, 929-9318.

18. Chan, K.W. The role of epistemological beliefs in Hong Kong preservice teachers' learning. Asia-Pac. Educ. Res. 2010, 19, 7-24. [CrossRef]

19. Eow, Y.L.; Ali, W.Z.B.; Mahmud, R.B.; Baki, R. Computer games development and appreciative learning approach in enhancing students' creative perception. Comput. Educ. 2010, 54, 146-161. [CrossRef]

20. Papadakis, S.; Kalogiannakis, M.; Zaranis, N. Comparing tablets and PCs in teaching mathematics: An attempt to improve mathematics competence in early childhood education. Presch. Prim. Educ. 2016, 4, 241-253. [CrossRef]

21. Papadakis, S.; Kalogiannakis, M.; Zaranis, N. The effectiveness of computer and tablet assisted intervention in early childhood students' understanding of numbers. An empirical study conducted in Greece. Educ. Inf. Technol. 2018, 23, 1849-1871.

22. Tan, P.J.B. An Empirical Study of How the Learning Attitudes of College Students toward English E-Tutoring Websites Affect Site Sustainability. Sustainability 2019, 11, 1748. [CrossRef]

23. Lim, B. Aesthetic discourses in early childhood settings: Dewey, Steiner, and Vygotsky. Early Child Dev. Care 2004, 174, 473-486. [CrossRef]

24. Fan, D.R.J. The relationship between nine-year consistent arts education and early childhood arts education. In Proceedings of the International Conference on "The Formation of the Teachers in the Arts and Humanities Field of Junior and Elementary School", New Taipei City, Taiwan, 21-28 December 2003; pp. 293-308.

25. Early Childhood Educare. Available online: https://www.ece.moe.edu.tw/.../ (accessed on April 12019 ).

26. Farris, A.V.; Sengupta, P. Democratizing children's computation: Learning computational science as aesthetic experience. Educ. Theory 2016, 66, 279-296. [CrossRef]

27. Chou, M.-J. Kindergarten Teachers' Information Technology Teaching Beliefs: The Critical Path Toward Teaching Effectiveness. Proced.-Soc. Behav. Sci. 2013, 8, 844. [CrossRef]

(C) 2019 by the authors. Licensee MDPI, Basel, Switzerland. This article is an open access article distributed under the terms and conditions of the Creative Commons Attribution (CC BY) license (http://creativecommons.org/licenses/by/4.0/). 